\title{
PERFORMANCE OF LEGUMES ON WEED SUPPRESSION WITH HYBRID MAIZE INTERCROPPING
}

\author{
Q. Naher, S. M. R. Karim ${ }^{1}$ and M.Begum ${ }^{1}$ \\ On- Farm Research Division, Bangladesh Agricultural Research Institute (BARI), Gazipur \\ ${ }^{1}$ Bangladesh Agricultural University, Mymensingh \\ Corresponding Author, E-mail: kakonbari@gmail.com
}

(Received: 22 November 2018, Accepted: 9 April 2019)

Key words: Maize, legume crop, intercropping, weed suppression, yield

\begin{abstract}
Field experiment was carried out at the Bangladesh Agricultural Research institute, Joydebpur, Gazipur during 2010 to 2011 to identify suitable legume crops with maize in maize + legume intercropping systems for better weed suppression, productivity and economic benefits in Rabi season. There were 17 treatments of which two sole crop of hybrid maize (Zea mays BARI Hybrid bhutta -9) (weed free and no weeding), three weed free sole crops of pea (SN), bushbean $(\mathrm{SN})$ and cowpea (SN) in Rabi season, and their intercropping. Twelve intercropping with different weeding regimes (no weeding, one hand weeding at 20 days after emergence (DAE), one hand weeding at $40 \mathrm{DAE}$, and two hand weeding at 20 and 40 DAE of maize-legume intercropping under normal row $(75 \mathrm{~cm} \times 25 \mathrm{~cm})$, and two rows of legumes in between two rows of maize were used. Among all intercropping, maize-pea with two hand weeding at 20 and $40 \mathrm{DAE}$ gave the lowest $\left(6.57 \mathrm{~g} \mathrm{~m}^{-2}\right.$ at harvest) weed dry weight and the highest weed control efficiency $(86 \%$ at harvest). Maize-pea with two hand weeding at 20 and 40 DAE gave the highest yield (maize: $7.58 \mathrm{t}$ ha ${ }^{-1}$; $6.27 \mathrm{t} \mathrm{ha}^{-1}$ pea), resource complementarily and profitability $(\mathrm{LER}=1.89, \mathrm{BCR}=4.19)$. Intercropping of two rows of pea in between two rows of maize with two hand weeding at 20 and $40 \mathrm{DAE}$ to be a promising practice for weed suppression and profitable maize + legume intercropping in Rabi season.
\end{abstract}

\section{Introduction}

Maize stands third position among cereal crops in Bangladesh and also in total production covering an area of 1.52 lac ha with an annual production around 8.87 lac $\mathrm{m}$ ton (BBS, 2011). In Bangladesh, the maximum grain yield of 14 t/ha from hybrid maize in rabi season was reported by Farid and Shil (2006). Various causes are responsible for reducing yield. Among the causes weed is the major factor for low yield of maize. Weeds are one of them (Karimmojeni et al., 2010). Weeds compete with plant nutrients, soil moisture, light and space against crop plants (Kandasamy, 2017). Although appropriately selected herbicides may perform an important role in weed reduction, increasing weed resistance to herbicides, high cost and negative effects of herbicides on environment have increased the need of non-chemical weed control in agro-ecosystems (Ahmad et al., 2013).Weed competition is high when maize crop is sown with wide spacing, which allows a high portion of ambient light to penetrate. It is possible that maize could be intercropped with a short-duration legume crop, however, to fill the uncovered spaces between the rows and thus (legume crop) act as the suppressed weed. 
Intercropping is widely practiced in the tropical and subtropical Asian countries because of its increased productivity and insurance against crop failure. It also helps to reduce weed populations, insect, pests infestation and risk of complete crop failure (Islam et al., 2013). Intercropping is an agricultural practice which can be used for decreasing the dependency on chemical herbicides in weed control (Banik et al., 2006) and defined as the growth of two or more crop species simultaneously in the same field during a growing season (Thayamini and Brintha, 2010). Maize based intercropping systems are often subjected to severe stress offered by weed. Several researchers have been reported on intercropping (ljoyah, 2012) and mostly focusing on cereal-legume based (Hugar and Palled, 2008).

Legumes can relocate fixed $\mathrm{N}$ to intercropped cereals through their joint growing period and this $\mathrm{N}$ is an imperative resource for the cereals (Bhagad et al., 2006).Maize suffers from severe weed competition and depending upon the intensity, nature, stages and duration of weed infestation, it causes yield losses from 28-100\% (Patel et al., 2006). Weed suppression in intercropping system, and more efficient use of environmental resources by component crops had been reported (Mashingaizde, 2004). In addition, weeds can deplete nutrients from soils (Sreenivas and Satyanarayana, 1996). Herbicides have simplified weed control and are extensively used, even replacing cultural weed control methods in several regions. Intercropping can suppress the weed growth more than the sole crops (Baumann et al., 2000).

There is only limited information available on herbicide-free weed management practices that provide adequate weed suppression while maintaining acceptable yields on weed suppression. Therefore, the objective of this study was to select the suitable legume crop in the intercropping system for maximum weed suppression and increased yields.

\section{Materials and Methods}

The experiment was conducted at the On-farm research field of Bangladesh Agricultural Research Institute, Joydebpur, Gazipur during rabi season of 2010-11. The experiment site was located at Chhiata Series under Agro-Ecological Zone28. Before opening the land, the soil samples were taken from the spots of the experimental area and analyzed from the Soil Science Division, BARI. The soil analysis showed that the soil of the experimental field was loam in texture and low in organic matter (1.16\%). The soil $\mathrm{pH}$ is 7.2 and contained very low amount of total nitrogen (0.061\%), phosphorus $\left(3 \mathrm{~g} \mathrm{~g} \mathrm{~g}^{-1}\right)$, sulphur $\left(0.6 \mu \mathrm{g} \mathrm{g} \mathrm{g}^{-1}\right)$, zinc $\left(3.54 \mu \mathrm{g} \mathrm{g} \mathrm{g}^{-1}\right)$, boron $\left(0.44 \mu \mathrm{g} \mathrm{g}^{-1}\right)$ and potassium $(0.13 \mathrm{meq} . / 100 \mathrm{~g}$ soil). The rainfall during the period was $189 \mathrm{~mm}$ in 2010-11. During the crop growth period average monthly maximum temperature was recorded in the month of April $\left(22.5^{\circ} \mathrm{C}\right)$ and the minimum was recorded in the month of January $10.51{ }^{\circ} \mathrm{C}$ in 2010-11. There were 17 treatments viz., sole maize (no weeding) = $\mathrm{T}_{1}$, Maize + Garden pea (no weeding) $=\mathrm{T}_{2}$, Maize + Garden pea (one hand weeding at $20 \mathrm{DAE}$ ) $=\mathrm{T}_{3}$, Maize + Garden pea (one hand weeding at $40 \mathrm{DAE}$ ) $=\mathrm{T}_{4}$, Maize + Garden pea (two hand weeding at 20 and $40 \mathrm{DAE}$ ) $=\mathrm{T}_{5}$, Maize + Bushbean (no weeding) $=\mathrm{T}_{6}$ Maize + Bushbean (one hand weeding at 20 $\mathrm{DAE})=\mathrm{T}_{7}$, Maize + Bushbean (one hand weeding at $40 \mathrm{DAE}$ ) $=\mathrm{T}_{8}$, Maize + Bushbean (two hand weeding at 20 and $40 \mathrm{DAE}$ ) $=\mathrm{T}_{9}$. Maize + Cowpea (no weeding) $=\mathrm{T}_{10}$, Maize + Cowpea (one hand weeding at $20 \mathrm{DAE}$ ) $=\mathrm{T}_{11}$, Maize + Cowpea (one hand weeding at $40 \mathrm{DAE}$ ) $=\mathrm{T}_{12}$, Maize + Cowpea (two hand weeding at 20 and $40 \mathrm{DAE})=\mathrm{T}_{13}$, Sole maize (weed free) $=\mathrm{T}_{14}$, Sole Garden 
pea (weed free) $=T_{15}$, Sole Bushbean (weed free) $=T_{16}$ and sole Cowpea (weed free) $=T_{17}$ were studied. Maize was sown in $75 \mathrm{~cm} \times 20 \mathrm{~cm}$ spacing both in sole and intercrop system. Planting arrangement in intercrop treatments, two rows of legumes accommodated between maize rows. The trials were laid out in a randomized complete block design with three replications. The plot size was $5.0 \mathrm{~m} \times 4.5 \mathrm{~m}$. Maize var. BARI Hybrid Maize-7, garden pea var. BARI Motorshuti-1, bushbean var. BARI Jharsheem-1 and cowpea var. BARI Felon-1 were used as test crops. Fertilizer was applied for maize at the rate of 250-50100-44-5-2 kg of $\mathrm{N}, \mathrm{P}, \mathrm{K}, \mathrm{S}, \mathrm{Zn}$ and $\mathrm{B} \mathrm{ha}{ }^{-1}$, respectively, from urea, triple super phosphate, murate of potash, gypsum, zinc sulphate and boric acid, respectively. Half amount of $\mathrm{N}$ and full dose of other fertilizers were incorporated into the soil at the time of final land preparation. The remaining urea was top dressed in two equal installments as top dressing at 8-10 leaf stage (30-35 DAS) and at tasseling stage (50-60 DAS) followed by irrigation. Fertilizers were applied for sole pea, bushbean and cowpea at the rate of 23-30-8, 12-9-13, 23-33-55 kg of $\mathrm{N}, \mathrm{P}, \mathrm{K} \mathrm{ha}^{-1}$, respectively from Urea, TSP, MoP, gypsum, zinc sulphate and boric acid, respectively. Half amount of urea and full amount of other fertilizers were applied at the time of final land preparation. Sowing of both maize and legumes were done on 27 November 2010. Weed management was done as per treatment specification. Green pods of pea and bushbean were manually collected in three installments at 55, 65 and 70 DAE while cowpea was harvested at 125 DAE. Maize was harvested at 155 DAE. Legume equivalent yield and maize equivalent yield were computed using the formula of Bandyopadhaya (1984).

Legume equivalent yield $=$ Yil $+($ Yim $\times \mathrm{Pm}) / \mathrm{Pl}$

Maize equivalent yield $=$ Yim $+($ Yil $\times \mathrm{Pl}) / \mathrm{Pm}$

Where,

Yil = Yield of intercrop legume $\left(\mathrm{t} \mathrm{ha}^{-1}\right)$

maize (t ha' ${ }^{-1}$ )

$\mathrm{Pm}=$ Selling price of maize $\quad \mathrm{Pl} \quad=$ Selling price of

legume

Land equivalent ratio (LER)

Land equivalent ratio (LER) was obtained according to Willey (1979) as follows:

LER $=\frac{\text { Yield of mazie as intercrop }}{\text { Yield of maize as sole crop }}+\frac{\text { Yield of legume as intercrop }}{\text { Yield of legume as sole crop }}$

Competitive ratio (CR) (Willey and Rao, 1980)

Competitive ratio of maize: $(\mathrm{CRm}):\{(\mathrm{Yim} / \mathrm{Ysm}) / \mathrm{Yil} / \mathrm{Ysl})\} \times(\mathrm{Zl} / \mathrm{Zm})$

Competitive ratio of Legume: (CRL) : $\{(\mathrm{Yil} / \mathrm{Ysl}) /(\mathrm{Yim} / \mathrm{Ysm})\} \times(\mathrm{Zm} / \mathrm{Zl})$

Where,

Ysm = Yield of sole maize $\quad$ Ysl = Yield of sole legume

Yim = Yield of intercrop maize Yil $=$ Yield of intercrop legume

$\mathrm{ZI}=$ Proportion of legume in intercrop $\mathrm{Zm}=$ Proportion of maize in intercrop

Weed control efficiency (WCE) was calculated using the following formula (Curz et al., 1986).

$\mathrm{WCE}=\frac{\mathrm{DWC}-\mathrm{DWT}}{\mathrm{DWC}} \times 100$

DWC $=$ Dry weight of weeds in the weedy check

DWT $=$ Dry weight of weeds in the weeding treatment

The collected data were statistically analyzed by using MSTAT program and the means were adjudged by using LSD. Economic analysis was also done. 


\section{Results and Discussion}

Weed density and weed dry weight were significantly affected by different intercropping systems and weeding regime (Table 1).The weed population was dominated by grasses with little contribution from broadleaf and sedges. Cynodon dactylon, Eleusine indica, Echinochloa crus-galli, Cyperus rotundus, Leersia hexandra, Enhydra fluctuans, Portuloca oleracea, Vicia sativa, Rumex maritimus were the common species dominating the community in the experimental plots. The highest weed population (2527337 and 162.7 at $20 \mathrm{DAE}, 40 \mathrm{DAE}$ and at harvest, respectively) and weed dry weight (59.62, 108.80 and $40.40 \mathrm{~g} \mathrm{~m}^{-2}$ at 20 $\mathrm{DAE}, 40 \mathrm{DAE}$ and at harvest, respectively) was found in no weeding sole maize $\left(\mathrm{T}_{1}\right)$ and the lowest in $\mathrm{T}_{5}$ \{Maize + pea (weeding at 20 and 40 DAE)\} treatment. Similar results were obtained by Islam (2002) and Liebman and Dyek (1993). Among the intercropping systems, the maximum weed population and weed dry biomass were recorded in $\left(\mathrm{T}_{10}\right)$ maize + cowpea with no weeding. This might be due to the slow initial growth and widen row spacing of cowpea which provided with the conductive condition for growth of weeds (Singh et al., 1980).

Table 1. Weed density and weed dry weight in different maize + legumes intercropping systems during the Rabi season of 2010-11

\begin{tabular}{|c|c|c|c|c|c|c|}
\hline \multirow[t]{2}{*}{ Treatment } & \multicolumn{3}{|c|}{ Weed density (no. $\mathrm{m}^{-2}$ ) } & \multicolumn{3}{|c|}{ Weed dry weight $\left(\mathrm{g} \mathrm{m}^{-2}\right)$} \\
\hline & $20 \mathrm{DAE}$ & $40 \mathrm{DAE}$ & $\begin{array}{l}\text { At harvest } \\
\text { of legumes }\end{array}$ & $20 \mathrm{DAE}$ & $40 \mathrm{DAE}$ & $\begin{array}{l}\text { At harvest } \\
\text { of legumes }\end{array}$ \\
\hline $\mathrm{T}_{1}$ & $252.7 \mathrm{a}$ & $337.0 \mathrm{a}$ & $162.7 \mathrm{a}$ & $59.62 \mathrm{a}$ & $108.8 \mathrm{a}$ & $40.40 \mathrm{a}$ \\
\hline $\mathrm{T}_{2}$ & $192.0 \mathrm{fg}$ & $238.3 \mathrm{~cd}$ & $117.7 \mathrm{c}$ & $41.54 \mathrm{bcd}$ & $61.63 \mathrm{~b}$ & $30.58 \mathrm{c}$ \\
\hline $\mathrm{T}_{3}$ & $201.0 \mathrm{def}$ & 49.33 ef & 59.33 ef & $42.37 \mathrm{~b}$ & $10.64 \mathrm{de}$ & $15.81 \mathrm{f}$ \\
\hline $\mathrm{T}_{4}$ & $194.3 \mathrm{efg}$ & $228.0 \mathrm{~d}$ & $45.67 \mathrm{~g}$ & $40.88 \mathrm{bcd}$ & $50.55 \mathrm{c}$ & $11.28 \mathrm{~g}$ \\
\hline $\mathrm{T}_{5}$ & $186.3 \mathrm{~g}$ & $41.00 \mathrm{f}$ & $22.67 \mathrm{i}$ & $39.96 \mathrm{~d}$ & $8.52 \mathrm{e}$ & $6.57 \mathrm{~h}$ \\
\hline $\mathrm{T}_{6}$ & 203.3 cde & $262.0 \mathrm{~b}$ & $138.7 \mathrm{~b}$ & $40.23 \mathrm{~d}$ & $62.95 \mathrm{~b}$ & 31.68 bc \\
\hline $\mathrm{T}_{7}$ & $207.0 \mathrm{bcd}$ & 52.33 ef & $72.00 \mathrm{~d}$ & 42.04 bc & $13.38 \mathrm{~d}$ & 20.46 e \\
\hline $\mathrm{T}_{8}$ & $210.7 b c$ & $241.3 \mathrm{~cd}$ & $62.00 \mathrm{e}$ & $40.87 \mathrm{bcd}$ & $53.87 \mathrm{c}$ & $14.12 \mathrm{f}$ \\
\hline $\mathrm{T}_{9}$ & $204.3 \mathrm{~cd}$ & $60.00 \mathrm{e}$ & $29.00 \mathrm{hi}$ & $40.19 \mathrm{~d}$ & $11.48 \mathrm{de}$ & $7.31 \mathrm{~h}$ \\
\hline $\mathrm{T}_{10}$ & $209.0 \mathrm{bcd}$ & $263.0 \mathrm{~b}$ & $141.3 \mathrm{~b}$ & $39.95 \mathrm{~d}$ & $61.73 \mathrm{~b}$ & $32.48 \mathrm{~b}$ \\
\hline $\mathrm{T}_{11}$ & $205.7 \mathrm{bcd}$ & $60.33 e$ & $72.33 \mathrm{~d}$ & $40.47 \mathrm{~cd}$ & $13.47 \mathrm{~d}$ & $24.25 \mathrm{~d}$ \\
\hline $\mathrm{T}_{12}$ & $214.7 \mathrm{~b}$ & $252.7 \mathrm{bc}$ & $54.33 \mathrm{f}$ & $41.20 \mathrm{bcd}$ & $51.71 \mathrm{c}$ & $14.57 \mathrm{f}$ \\
\hline $\mathrm{T}_{13}$ & $207.3 \mathrm{bcd}$ & 55.00 ef & $35.00 \mathrm{~h}$ & $40.99 \mathrm{bcd}$ & $11.42 \mathrm{de}$ & $7.53 \mathrm{~h}$ \\
\hline LSD & 9.343 & 15.09 & 7.598 & 1.711 & 4.484 & 1.862 \\
\hline CV $(\%$ & 2.90 & 5.88 & 6.26 & 2.59 & 7.19 & 6.04 \\
\hline
\end{tabular}

$\mathrm{T}_{1}=$ Sole maize (no weeding), $\mathrm{T}_{2}=$ Maize + Garden pea (no weeding), $\mathrm{T}_{3}=$ Maize + Garden pea (weeding at $20 \mathrm{DAE}), \mathrm{T}_{4}=$ Maize + Garden pea (weeding at $40 \mathrm{DAE}$ ), $\mathrm{T}_{5}=$ Maize + Garden pea (weeding at 20 and $40 \mathrm{DAE}), \mathrm{T}_{6}=$ Maize + Bushbean (no weeding), $\mathrm{T}_{7}=$ Maize + Bushbean (weeding at $20 \mathrm{DAE}), \mathrm{T}_{8}=$ Maize + Bushbean (weeding at $40 \mathrm{DAE}$ ), $\mathrm{T}_{9}=$ Maize + Bushbean (weeding at 20 and $40 \mathrm{DAE}), \mathrm{T}_{10}=$ Maize + Cowpea (no weeding), $\mathrm{T}_{11}=$ Maize + Cowpea (weeding at $20 \mathrm{DAE}), \mathrm{T}_{12}=$ Maize + Cowpea (weeding at $40 \mathrm{DAE}$ ), $\mathrm{T}_{13}=$ Maize + Cowpea (weeding at 20 and $40 \mathrm{DAE}$ )

Weed control efficiency of different treatments varied from $15-26.18 \%$ at 20 $\mathrm{DAE}, 22-87.8 \%$ at $40 \mathrm{DAE}$ and $13-86 \%$ at harvest (Table 2). The highest weed control efficiency (WCE) was recorded in maize + pea $(86.14 \%)$ followed by maize + bushbean (82.19\%) and maize + cowpea (78.46\%) intercropping. Among the intercropping systems, un-weeded maize + cowpea (13-22\%) intercropping plot gave the lower WCE. Among all the weed control treatments, maize + pea 
with two hand weeding had the highest weed control efficiency (26-88\%) while it was $19-82 \%$ at maize + bushbean and $18-83 \%$ at maize + cowpea treatment. The maximum weed control efficiency was associated with maize + pea intercropping, and it was minimum with maize + cowpea intercropping system. The reduction in weed population and weed dry biomass in intercropping systems may be attributed to shading effect and competition stress created by canopy of more number of crop plants in a unit area having suppressive effect on associated weeds. Similar results were reported by Kumar and Reddy (2000).

Table 2. Weed control efficiency (\%) of different intercropping systems under varying weeding regimes during the Rabi season of 2010-11

\begin{tabular}{cccc}
\hline Treatment & $20 \mathrm{DAE}$ & $40 \mathrm{DAE}$ & At harvest of legumes \\
\hline $\mathrm{T}_{2}$ & $24.02 \mathrm{ab}$ & $29.30 \mathrm{~cd}$ & $27.60 \mathrm{f}$ \\
$\mathrm{T}_{3}$ & $20.39 \mathrm{bcd}$ & $85.36 \mathrm{ab}$ & $63.39 \mathrm{~d}$ \\
$\mathrm{~T}_{4}$ & $23.09 \mathrm{abc}$ & $32.33 \mathrm{c}$ & $71.85 \mathrm{c}$ \\
$\mathrm{T}_{5}$ & $26.18 \mathrm{a}$ & $87.82 \mathrm{a}$ & $86.14 \mathrm{a}$ \\
$\mathrm{T}_{6}$ & $19.49 \mathrm{cde}$ & $22.28 \mathrm{e}$ & $14.71 \mathrm{~g}$ \\
$\mathrm{~T}_{7}$ & $18.08 \mathrm{def}$ & $84.47 \mathrm{ab}$ & $55.72 \mathrm{e}$ \\
$\mathrm{T}_{8}$ & $16.58 \mathrm{ef}$ & $28.42 \mathrm{~cd}$ & $61.88 \mathrm{~d}$ \\
$\mathrm{~T}_{9}$ & $19.13 \mathrm{de}$ & $82.20 \mathrm{~b}$ & $82.19 \mathrm{ab}$ \\
$\mathrm{T}_{10}$ & $17.24 \mathrm{def}$ & $21.96 \mathrm{e}$ & $13.13 \mathrm{~g}$ \\
$\mathrm{~T}_{11}$ & $18.60 \mathrm{def}$ & $82.09 \mathrm{~b}$ & $55.55 \mathrm{e}$ \\
$\mathrm{T}_{12}$ & $15.00 \mathrm{f}$ & $25.01 \mathrm{de}$ & $66.63 \mathrm{~d}$ \\
$\mathrm{~T}_{13}$ & $17.95 \mathrm{def}$ & $83.68 \mathrm{ab}$ & $78.46 \mathrm{~b}$ \\
\hline LSD $(0.05)$ & 3.789 & 4.553 & 4.833 \\
CV (\%) & 11.39 & 4.85 & 5.06 \\
\hline
\end{tabular}

$\mathrm{T}_{2}=$ Maize + Garden pea (no weeding), $\mathrm{T}_{3}=$ Maize + Garden pea (weeding at $20 \mathrm{DAE}$ ), $\mathrm{T}_{4}=$ Maize + Garden pea (weeding at $40 \mathrm{DAE}$ ), $\mathrm{T}_{5}=$ Maize + Garden pea (weeding at 20 and 40 $\mathrm{DAE}), \mathrm{T}_{6}=$ Maize + Bushbean (no weeding), $\mathrm{T}_{7}=$ Maize + Bushbean (weeding at $20 \mathrm{DAE}$ ), $\mathrm{T}_{8}=$ Maize + Bushbean (weeding at $40 \mathrm{DAE}$ ), $\mathrm{T}_{9}=$ Maize + Bushbean (weeding at 20 and 40 $\mathrm{DAE}), \mathrm{T}_{10}=$ Maize + Cowpea (no weeding), $\mathrm{T}_{11}=$ Maize + Cowpea (weeding at $\left.20 \mathrm{DAE}\right), \mathrm{T}_{12}=$ Maize + Cowpea (weeding at $40 \mathrm{DAE}), \mathrm{T}_{13}=$ Maize + Cowpea (weeding at 20 and $40 \mathrm{DAE}$ )

\section{Effect on maize yield and yield attributes}

Yield and yield contributing characters of maize were influenced significantly by different intercropping systems and weeding regime treatment (Table 3). The maximum length of cob (19.37) was recorded in weed free sole maize $\left(\mathrm{T}_{14}\right)$ which was statistically similar with maize + pea intercropping with two hand weeding $(18.37 \mathrm{~cm})$ and no weeding sole maize (18.30). The lowest cob length $(15.27 \mathrm{~cm})$ was obtained from no weeding maize + cowpea intercropping systems which was statistically at par with no weeding maize + pea and maize + bushbean intercropping systems $(16.23 \mathrm{~cm}$ and $16.30 \mathrm{~cm})$. Higher number of grains $\mathrm{cob}^{-1}$ was recorded from weed free sole maize (593.3) which was statistically identical to maize + pea with two hand weeding and maize + bushbean intercropping systems. The lowest grains $\mathrm{cob}^{-1}$ was in no weeding maize + cowpea association. The highest 1000-grain weight was obtained from weed free sole maize $(312.5 \mathrm{~g})$ than unweeded sole maize plot (258.5 g). Among the intercropping systems, maize + pea produced higher grain weight (295.2 g) than maize + bushbean and maize + cowpea association. Lower 1000grain weight was obtained from maize + cowpea association.

Table 3. Yield attributes of maize in maize + legumes intercropping systems during the Rabi season of 2010-11 


\begin{tabular}{cccc}
\hline Treatment & Cob length $(\mathrm{cm})$ & No. of grains cob & 1000-grain wt. (g) \\
\hline $\mathrm{T}_{1}$ & $18.30 \mathrm{ab}$ & $567.0 \mathrm{abc}$ & $258.5 \mathrm{e}$ \\
$\mathrm{T}_{2}$ & $16.23 \mathrm{de}$ & $484.0 \mathrm{gh}$ & $278.6 \mathrm{bcde}$ \\
$\mathrm{T}_{3}$ & $16.73 \mathrm{~cd}$ & $502.7 \mathrm{fg}$ & $285.0 \mathrm{bcd}$ \\
$\mathrm{T}_{4}$ & $17.67 \mathrm{bc}$ & $560.7 \mathrm{bcd}$ & $285.0 \mathrm{bcd}$ \\
$\mathrm{T}_{5}$ & $18.37 \mathrm{ab}$ & $585.7 \mathrm{ab}$ & $295.2 \mathrm{ab}$ \\
$\mathrm{T}_{6}$ & $16.30 \mathrm{de}$ & $475.7 \mathrm{~h}$ & $272.5 \mathrm{bcde}$ \\
$\mathrm{T}_{7}$ & $17.27 \mathrm{bcd}$ & $542.0 \mathrm{cde}$ & $275.5 \mathrm{bcde}$ \\
$\mathrm{T}_{8}$ & $17.77 \mathrm{bc}$ & $563.0 \mathrm{bc}$ & $277.1 \mathrm{bcde}$ \\
$\mathrm{T}_{9}$ & $17.87 \mathrm{bc}$ & $575.3 \mathrm{ab}$ & $289.9 \mathrm{abc}$ \\
$\mathrm{T}_{10}$ & $15.27 \mathrm{e}$ & $421.0 \mathrm{i}$ & $256.7 \mathrm{e}$ \\
$\mathrm{T}_{11}$ & $16.60 \mathrm{~cd}$ & $519.0 \mathrm{ef}$ & $264.0 \mathrm{de}$ \\
$\mathrm{T}_{12}$ & $16.77 \mathrm{~cd}$ & $519.3 \mathrm{ef}$ & $269.0 \mathrm{cde}$ \\
$\mathrm{T}_{13}$ & $16.70 \mathrm{~cd}$ & $535.7 \mathrm{de}$ & $287.2 \mathrm{bc}$ \\
$\mathrm{T}_{14}$ & $19.37 \mathrm{a}$ & $593.3 \mathrm{a}$ & $312.5 \mathrm{a}$ \\
\hline LSD (0.05) & 1.141 & 24.52 & 22.759 \\
CV (\%) & 3.95 & 2.75 & 4.86 \\
\hline
\end{tabular}

$\mathrm{T}_{1}=$ Sole maize (no weeding), $\mathrm{T}_{2}=$ Maize + Garden pea (no weeding), $\mathrm{T}_{3}=$ Maize + Garden pea (weeding at $20 \mathrm{DAE}$ ), $\mathrm{T}_{4}=$ Maize + Garden pea (weeding at $40 \mathrm{DAE}$ ), $\mathrm{T}_{5}=$ Maize + Garden pea (weeding at 20 and $40 \mathrm{DAE}$ ), $\mathrm{T}_{6}=$ Maize + Bushbean (no weeding), $\mathrm{T}_{7}=$ Maize + Bushbean (weeding at $20 \mathrm{DAE}$ ), $\mathrm{T}_{8}=$ Maize + Bushbean (weeding at $40 \mathrm{DAE}$ ), $\mathrm{T}_{9}=$ Maize + Bushbean (weeding at 20 and $40 \mathrm{DAE}$ ), $\mathrm{T}_{10}=$ Maize + Cowpea (no weeding), $\mathrm{T}_{11}=$ Maize + Cowpea (weeding at $20 \mathrm{DAE}$ ), $\mathrm{T}_{12}=$ Maize + Cowpea (weeding at $40 \mathrm{DAE}$ ), $\mathrm{T}_{13}=$ Maize + Cowpea (weeding at 20 and $40 \mathrm{DAE}$ )

Significant influence was observed in grain yield of maize under different intercropping systems (Fig. 1). The highest grain yield $\left(8.80 \mathrm{t} \mathrm{ha}^{-1}\right)$ was obtained from weed free sole maize while the lowest yield $\left(4.64 \mathrm{t} \mathrm{ha}^{-1}\right)$ showed in unweeded maize + cowpea intercropping plot. Among the intercropping systems maize + pea with two hand weeding at 20 and 40 DAE recorded highest grain yield than all other intercropping treatments.

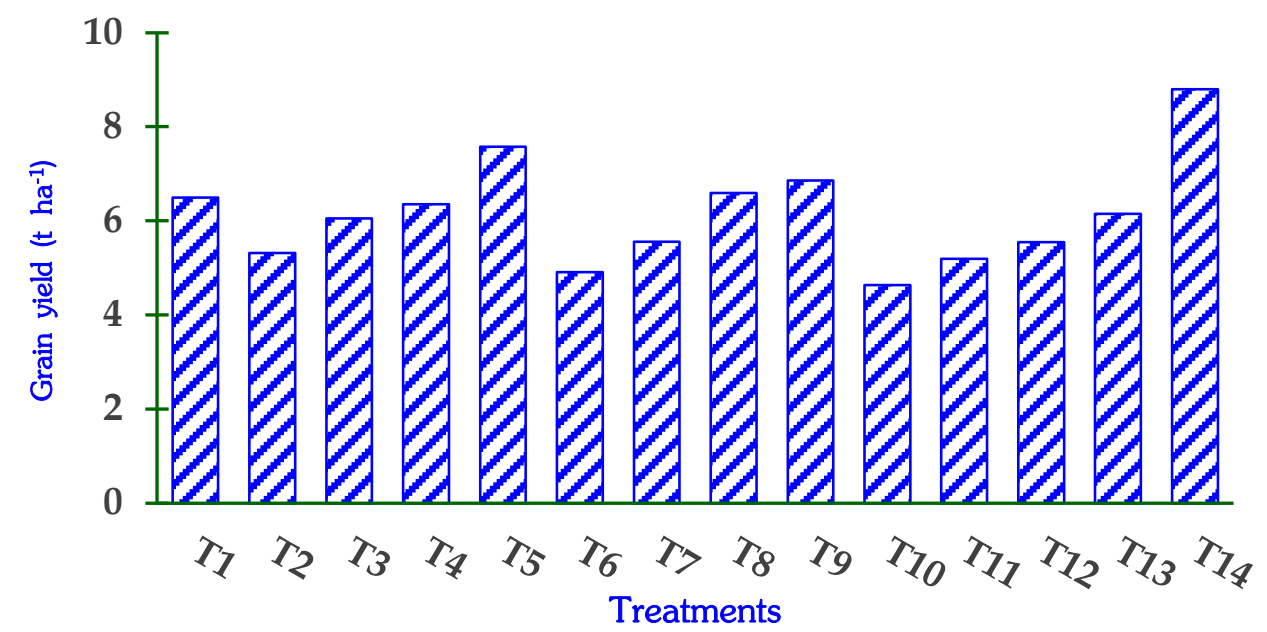

Fig. 1. Grain yield of maize in maize + legumes intercropping systems during the Rabi season of 2010-11

When maize was intercropped with pea, higher grain yield was obtained $(7.58 \mathrm{t}$ $\mathrm{ha}^{-1}$ ) than that of maize + bushbean and cowpea intercropping association. This might be due to less inter-species competition for nutrient especially nitrogen between maize and pea, in addition, as a leguminous crop pea supplies 
supplementary nitrogen to maize that aided to gain statistically similar grain yield of maize. The results are in agreement with those of Singh et al. (2000).

\section{Yield and yield attributes of legumes}

Yield and yield attributes of legumes were significantly influenced by the treatments (Table 4). Pods per plant were significantly influenced by intercropping systems with varying weeding regime. Higher number of pods per plant was observed in maize + bushbean with two hand weedings (13) intercropping systems which was statistically similar with all the treatments of maize + bushbean intercropping and respective sole crop. Sole treatments showed higher pods per plant. Reduced inter and intra species competition for growth factors might have contributed towards higher number of pods per plant of sole legume..Higher pod yield was produced from maize + bushbean intercropping system (9.13 $\mathrm{t} \mathrm{ha}^{-1}$ ) with two hand weeding which was followed by one hand weeding at $20 \mathrm{DAE}\left(8.23 \mathrm{t} \mathrm{ha}^{-1}\right)$ and $40 \mathrm{DAE}\left(7.63 \mathrm{t} \mathrm{ha}^{-1}\right)$, respectively (Fig. $2)$. Within maize + pea intercropping two hand weeding gave higher pod yield (4.93 $\mathrm{t} \mathrm{ha}^{-1}$ ) than one hand weeding at $20 \mathrm{DAE}\left(4.43 \mathrm{t} \mathrm{ha}^{-1}\right)$, at $40 \mathrm{DAE}(4.30$ $\left.\mathrm{t} \mathrm{ha}^{-1}\right)$ and no weeding treatment $\left(3.1 \mathrm{t} \mathrm{ha}^{-1}\right)$. Weed free sole cowpea gave higher grain yield $\left(0.59 \mathrm{t} \mathrm{ha}^{-1}\right)$ than cowpea with two and one hand weeding treatments. No hand weeding gave lower grain than the sole situation. Besides, sole legume grown in sufficient sunlight due to higher photosynthesis occurred at the vegetative to pod formation stage then more carbohydrate was translocated to pod, so pod yield was higher. Sarker and Pal (2004) and Razzaque et al. (2007) also reported higher pod yield of groundnut was obtained from sole crop. The pod yield of legumes in intercropping situation was considerably reduced. This corroborates with the findings of Sarkar and Pal (2004) and Razzaqueet al. (2007).

Table 4. Yield attributes of legumes in maize + legumes intercropping system during the Rabi season of 2009-10

\begin{tabular}{ccc}
\hline Treatment & Pods plant ${ }^{-1}($ no.) & Pod length $(\mathrm{cm})$ \\
\hline $\mathrm{T}_{2}$ & $7.333 \mathrm{cde}$ & $6.933 \mathrm{e}$ \\
$\mathrm{T}_{3}$ & $8.333 \mathrm{~cd}$ & $7.367 \mathrm{de}$ \\
$\mathrm{T}_{4}$ & $9.000 \mathrm{bc}$ & $7.833 \mathrm{de}$ \\
$\mathrm{T}_{5}$ & $11.000 \mathrm{ab}$ & $7.600 \mathrm{de}$ \\
$\mathrm{T}_{6}$ & $12.330 \mathrm{a}$ & $10.400 \mathrm{c}$ \\
$\mathrm{T}_{7}$ & $11.330 \mathrm{ab}$ & $10.700 \mathrm{c}$ \\
$\mathrm{T}_{8}$ & $11.670 \mathrm{a}$ & $10.730 \mathrm{c}$ \\
$\mathrm{T}_{9}$ & $13.000 \mathrm{a}$ & $10.670 \mathrm{c}$ \\
$\mathrm{T}_{10}$ & $6.333 \mathrm{de}$ & $12.600 \mathrm{~b}$ \\
$\mathrm{~T}_{11}$ & $5.667 \mathrm{e}$ & $12.870 \mathrm{ab}$ \\
$\mathrm{T}_{12}$ & $6.667 \mathrm{cde}$ & $13.630 \mathrm{a}$ \\
$\mathrm{T}_{13}$ & $7.667 \mathrm{cde}$ & $13.770 \mathrm{a}$ \\
$\mathrm{T}_{15}$ & $12.330 \mathrm{a}$ & $8.067 \mathrm{~d}$ \\
$\mathrm{~T}_{16}$ & $12.000 \mathrm{a}$ & $12.170 \mathrm{~b}$ \\
$\mathrm{~T}_{17}$ & $11.670 \mathrm{a}$ & $12.700 \mathrm{~b}$ \\
\hline $\mathrm{LSD}_{(0.05)}$ & 2.234 & 0.869 \\
$\mathrm{CV}(\%)$ & 13.69 & $4.93 \mathrm{~d}$ \\
\hline
\end{tabular}




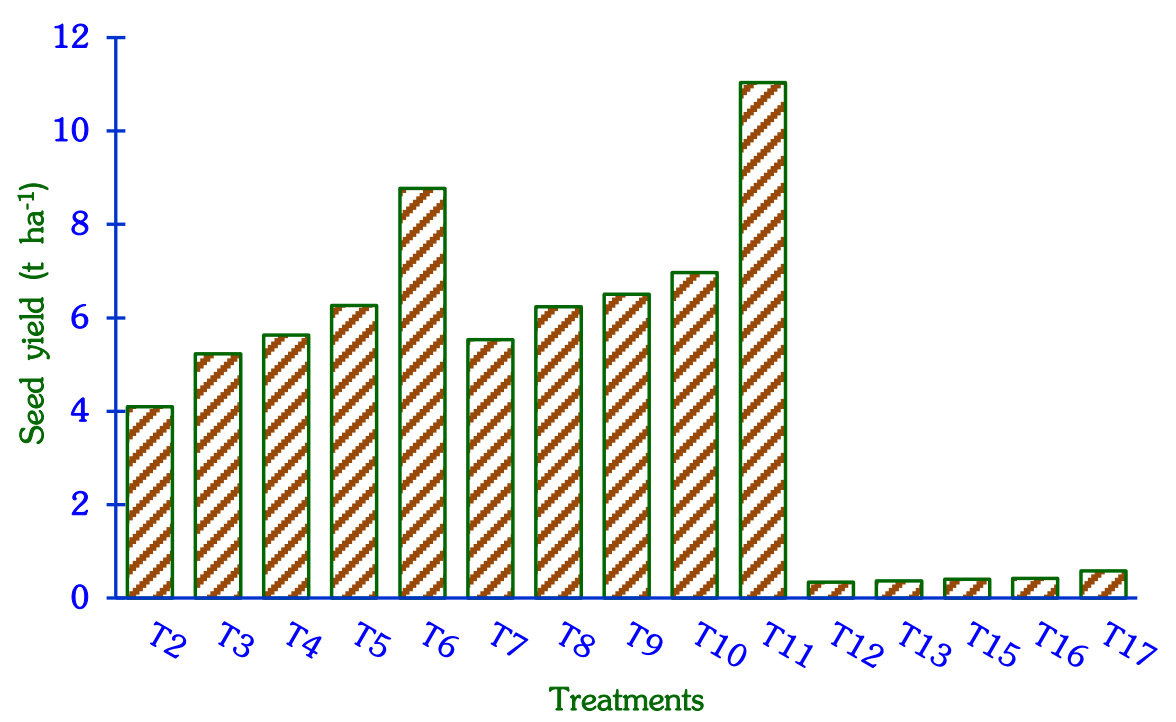

Fig. 2. Seed yield of legumes in maize + legumes intercropping system during the Rabi season of $2010-11$

$\mathrm{T}_{1}=$ Sole maize (no weeding, $\mathrm{T}_{2}=$ Maize + Garden pea (no weeding), $\mathrm{T}_{3}=$ Maize + Garden pea (weeding at $20 \mathrm{DAE}$ ), $\mathrm{T}_{4}=$ Maize + Garden pea (weeding at $40 \mathrm{DAE}$ ), $\mathrm{T}_{5}=$ Maize + Garden pea (weeding at 20 and $40 \mathrm{DAE}$ ), $\mathrm{T}_{6}=$ Maize + Bushbean (no weeding), $\mathrm{T}_{7}=$ Maize + Bushbean (weeding at $20 \mathrm{DAE}$ ), $\mathrm{T}_{8}=$ Maize + Bushbean (weeding at $40 \mathrm{DAE}$ ), $\mathrm{T}_{9}=$ Maize + Bushbean (weeding at 20 and $40 \mathrm{DAE}$ ), $\mathrm{T}_{10}=$ Maize + Cowpea (no weeding), $\mathrm{T}_{11}=$ Maize + Cowpea (weeding at $20 \mathrm{DAE}$ ), $\mathrm{T}_{12}=$ Maize + Cowpea (weeding at $40 \mathrm{DAE}$ ), $\mathrm{T}_{13}=$ Maize + Cowpea (weeding at 20 and $40 \mathrm{DAE}$ ), $\mathrm{T}_{15}=$ Sole Garden pea (weed free), $\mathrm{T}_{16}=$ Sole Bushbean (weed free), $\mathrm{T}_{17}=$ Sole Cowpea (weed free)

\section{Assessment of competition and evaluation of intercrop productivity}

Competitive ratio: Competitive ratio (CR) values showed the variability in competitive ability of component crops with the variation of intercropping (Table 5). The results indicated that maize was a better competitor when it was sown with pea and bushbean and a poor competitor when it was sown with cowpea. In maize + pea intercropping with different weeding regimes, maize with no weeding treatment showed higher competition to pea and to weeds. It was followed by one weeding at $20 \mathrm{DAE}$ and two weeding at 20 and $40 \mathrm{DAE}$. In maize + bushbean intercropping, maize was better competitor when two hand weeding were done. Similar results were also obtained by Patra et al. (2000). The difference in competitive ratio of maize and legumes in maize + cowpea intercropped was minimum indicating similar competitive ability of maize and cowpea.

\section{Land equivalent ratio (LER)}

The highest land equivalent ratio (LER) was recorded in maize + pea (1.89) with two hand weedings. The lowest LER value was found in maize + cowpea with no weeding (1.29) treatment. LER 1.89 indicates that 89 percent yield advantage is obtained when grown as intercrops compared to growing sole crops (Table 5).The results are in agreement with that of Quayyum et al. (1987), Patra et al. (2000), Santalla et al. (2001) and Razzaque et al. (2007). 
Table 5. Competitive ratio and LER of maize and legumes in intercropping systems in the Rabi season of 2010-11

\begin{tabular}{ccccc}
\hline Treatment & \multicolumn{3}{c}{ Competitive ratio } & $\begin{array}{c}\text { Land equivalent } \\
\text { ratio (LER) }\end{array}$ \\
\cline { 2 - 3 } & Maize & Legume & Difference & 1.00 \\
$\mathrm{~T}_{1}$ & - & Pea & & 1.30 \\
$\mathrm{~T}_{2}$ & 1.17 & 0.85 & +0.32 & 1.53 \\
$\mathrm{~T}_{3}$ & 1.04 & 0.96 & +0.08 & 1.74 \\
$\mathrm{~T}_{4}$ & 1.02 & 0.98 & +0.04 & 1.89 \\
$\mathrm{~T}_{5}$ & 1.09 & 0.91 & +0.18 & \\
& - & Bush bean & +0.02 & 1.26 \\
$\mathrm{~T}_{6}$ & 1.01 & 11.80 & +0.04 & 1.42 \\
$\mathrm{~T}_{7}$ & 1.02 & 13.10 & +0.17 & 1.61 \\
$\mathrm{~T}_{8}$ & 1.14 & 13.83 & +0.23 & 1.69 \\
$\mathrm{~T}_{9}$ & 1.12 & 1.27 & -0.39 & 1.29 \\
& - & Cowpea & -0.31 & 1.43 \\
$\mathrm{~T}_{10}$ & 0.83 & 0.99 & -0.38 & 1.54 \\
$\mathrm{~T}_{11}$ & 0.86 & 0.98 & -0.24 & 1.67 \\
$\mathrm{~T}_{12}$ & 0.83 & 0.87 & & 1.00 \\
$\mathrm{~T}_{13}$ & 0.89 & 0.89 & - & 1.00 \\
$\mathrm{~T}_{14}$ & - & - & & 1.00 \\
$\mathrm{~T}_{15}$ & - & & & \\
$\mathrm{T}_{16}$ & & & & \\
$\mathrm{~T}_{17}$ & & & & \\
\hline
\end{tabular}

$\mathrm{T}_{1}=$ Sole maize (no weeding, $\mathrm{T}_{2}=$ Maize + Garden pea (no weeding), $\mathrm{T}_{3}=$ Maize + Garden pea (weeding at $20 \mathrm{DAE}$ ), $\mathrm{T}_{4}=$ Maize + Garden pea (weeding at $40 \mathrm{DAE}$ ), $\mathrm{T}_{5}=$ Maize + Garden pea (weeding at 20 and $40 \mathrm{DAE}), \mathrm{T}_{6}=$ Maize + Bushbean (no weeding), $\mathrm{T}_{7}=$ Maize + Bushbean (weeding at $20 \mathrm{DAE}), \mathrm{T}_{8}=$ Maize + Bushbean (weeding at $\left.40 \mathrm{DAE}\right), \mathrm{T}_{9}=$ Maize + Bushbean (weeding at 20 and $40 \mathrm{DAE}), \mathrm{T}_{10}=$ Maize + Cowpea (no weeding), $\mathrm{T}_{11}=$ Maize + Cowpea (weeding at $20 \mathrm{DAE}$ ), $\mathrm{T}_{12}=$ Maize + Cowpea (weeding at $\left.40 \mathrm{DAE}\right), \mathrm{T}_{13}=$ Maize + Cowpea (weeding at 20 and $40 \mathrm{DAE}$ ), $\mathrm{T}_{15}=$ Sole Garden pea (weed free), $\mathrm{T}_{16}=$ Sole Bushbean (weed free), $\mathrm{T}_{17}=$ Sole Cowpea (weed free)

\section{Intercrop efficiency based on equivalent yield and benefit cost}

The performance of maize + legume intercropping systems was also evaluated based on equivalent yield (Bandyopadhyay, 1984). The maximum maize equivalent yield $\left(20.12 \mathrm{t} \mathrm{ha}^{-1}\right.$ ) was obtained from $\mathrm{T}_{5}$ (maize + pea with two hand weeding at 20 and $40 \mathrm{DAE}$ ) treatment (Table 6). Lower maize equivalent yield $(6.35 \mathrm{t}$ $\left.h^{-1}\right)$ was obtained from $T_{10}$ which was followed by $T_{11}\left(7.03 t h^{-1}\right), T_{1}(6.50 \mathrm{t}$ $\mathrm{ha}^{-1}$ ) and $\mathrm{T}_{12}\left(7.99 \mathrm{t} \mathrm{ha}^{-1}\right)$, respectively. On the other hand, among the intercrop bushbean equivalent yield was higher than pea and cowpea. Lower legume equivalent yield $\left(0.6 \mathrm{t} \mathrm{ha}{ }^{-1}\right)$ was obtained in sole crop of cowpea $\left(\mathrm{T}_{17}\right)$. Many plant studies also reported higher economic advantage in intercropping system than sole crop (Saha et al., 2001 and Begum et al., 2010).

Table 6 showed that the highest gross return (Tk. 90347 ha $^{-1}$ ) was obtained from maize as sole with weed free condition $\left(\mathrm{T}_{14}\right)$. Pea in sole situation also showed much higher gross return (Tk. $175340 \mathrm{ha}^{-1}$ ) than other bushbean and cowpea. Among intercropping, maize + pea with two hand weeding treatment gave higher gross return in both maize and pea crops which was followed by maize + bushbean with two hand weeding. Higher total gross return of Tk. $203263 \mathrm{ha}^{-1}$ was obtained from the same treatment in intercropping situation than any other sole crop cultivation. The highest cost of cultivation was noted in sole pea and bushbean treatment (Tk. $65900 \mathrm{ha}^{-1}$ ) and the lowest cost of cultivation of Tk. $20300 \mathrm{ha}^{-1}$ was recorded from sole cowpea. Net return varied from Tk. 9035 to 154748 ha $^{-1}$ among the treatments. The highest net return was recorded from maize + pea intercropping with two hand weeding (Tk. 154748 ha $\left.^{-1}\right)$. 
Table 6. Equivalent yield and cost benefit analysis of different maize + legume intercropping systems during Rabi season of 2010-11

\begin{tabular}{|c|c|c|c|c|c|c|}
\hline \multirow[t]{2}{*}{ Treatment } & \multicolumn{2}{|c|}{$\begin{array}{l}\text { Equivalent yield } \\
\left.(\mathrm{t} \mathrm{ha})^{-1}\right)\end{array}$} & $\begin{array}{c}\text { Gross } \\
\text { Return }\end{array}$ & \multirow{2}{*}{$\begin{array}{l}\text { Cost of } \\
\text { cultivation } \\
\left(\text { Tk. ha }{ }^{-1}\right)\end{array}$} & \multirow{2}{*}{$\begin{array}{c}\text { Gross } \\
\text { margin } \\
\left(\text { Tk. ha }{ }^{-1}\right)\end{array}$} & \multirow[t]{2}{*}{ BCR } \\
\hline & Maize & Legume & (Tk. $\left.\quad h^{-1}\right)$ & & & \\
\hline $\mathrm{T}_{1}$ & 6.50 & - & 70505 & 40500 & 30005 & 1.74 \\
\hline $\mathrm{T}_{2}$ & 13.52 & 6.76 & 136968 & 45515 & 91453 & 3.01 \\
\hline $\mathrm{T}_{3}$ & 16.52 & 8.26 & 167143 & 47550 & 119593 & 3.52 \\
\hline $\mathrm{T}_{4}^{\circ}$ & 17.62 & 8.81 & 178080 & 47500 & 130580 & 3.75 \\
\hline $\mathrm{T}_{5}$ & 20.12 & 10.06 & 203263 & 48515 & 154748 & 4.19 \\
\hline $\mathrm{T}_{6}$ & 10.45 & 10.45 & 106289 & 45515 & 60774 & 2.34 \\
\hline $\mathrm{T}_{7}$ & 11.80 & 11.80 & 119812 & 47500 & 72312 & 2.52 \\
\hline $\mathrm{T}_{8}^{\prime}$ & 13.10 & 13.10 & 132863 & 47500 & 85363 & 2.80 \\
\hline $\mathrm{T}_{9}$ & 13.83 & 13.83 & 140079 & 49515 & 90564 & 2.83 \\
\hline $\mathrm{T}_{10}$ & 6.35 & 1.27 & 65330 & 39000 & 26330 & 1.68 \\
\hline $\mathrm{T}_{11}^{10}$ & 7.03 & 1.41 & 72065 & 40000 & 32065 & 1.80 \\
\hline $\mathrm{T}_{12}^{11}$ & 7.59 & 1.52 & 77674 & 40000 & 37674 & 1.94 \\
\hline $\mathrm{T}_{13}^{12}$ & 8.25 & 1.65 & 84352 & 42515 & 41837 & 1.98 \\
\hline $\mathrm{T}_{14}^{10}$ & - & 1.00 & 90347 & 45515 & 44832 & 1.98 \\
\hline $\mathrm{T}_{15}^{14}$ & - & 8.77 & 175340 & 55000 & 120340 & 3.19 \\
\hline $\mathrm{T}_{16}^{15}$ & - & 11.03 & 110300 & 55000 & 55300 & 2.01 \\
\hline $\mathrm{T}_{17}$ & 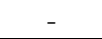 & 0.59 & 29335 & 20300 & 9035 & 1.45 \\
\hline
\end{tabular}

$\mathrm{T}_{1}=$ Sole maize (no weeding, $\mathrm{T}_{2}=$ Maize + Garden pea (no weeding), $\mathrm{T}_{3}=$ Maize + Garden pea (weeding at $20 \mathrm{DAE}$ ), $\mathrm{T}_{4}=$ Maize + Garden pea (weeding at $40 \mathrm{DAE}$ ), $\mathrm{T}_{5}=$ Maize + Garden pea (weeding at 20 and $40 \mathrm{DAE}$ ), $\mathrm{T}_{6}=$ Maize + Bushbean (no weeding), $\mathrm{T}_{7}=$ Maize + Bushbean (weeding at $20 \mathrm{DAE}), \mathrm{T}_{8}=$ Maize + Bushbean (weeding at $40 \mathrm{DAE}$ ), $\mathrm{T}_{9}=$ Maize + Bushbean (weeding at 20 and $40 \mathrm{DAE}$ ), $\mathrm{T}_{10}=$ Maize + Cowpea (no weeding), $\mathrm{T}_{11}=$ Maize + Cowpea (weeding at $20 \mathrm{DAE}$ ), $\mathrm{T}_{12}=$ Maize + Cowpea (weeding at $40 \mathrm{DAE}$ ), $\mathrm{T}_{13}=$ Maize + Cowpea (weeding at 20 and $40 \mathrm{DAE}$ ), $\mathrm{T}_{15}=$ Sole Garden pea (weed free), $\mathrm{T}_{16}=$ Sole Bushbean (weed free), $\mathrm{T}_{17}=$ Sole Cowpea (weed free)

The highest BCR was found in maize + pea with two hand weeding (4.19) whereas sole cowpea and maize + cowpea with no weeding intercropping gave the lowest BCR than any other treatments (1.45 to 1.68).

\section{Conclusion}

The results revealed that intercropping of two rows of pea in between two rows of maize $(75 \mathrm{~cm} \times 20 \mathrm{~cm}$ ) with two hand weeding at 20 and 40 DAE to be a profitable practice for weed-suppression and a higher economic return.

\section{References}

Ahmad, M., M.J. Khan and D. Muhammad. 2013. Response of maize to different phosphorus levels under calcareous soil conditions. Sarhad J. Agric. 29(1): 43-48.

Bandyopadhyay, S.N. 1984. Nitrogen and water relations in grain sorghum-legume intercropping systems. Ph. D. Dissertation, Indian Agricultural Research Institute, New Delhi.

Banik, P., A. Midya, B.K. Sarkar and S.S. Ghose. 2006. Wheat and chickpea intercropping systems in an additive series experiment: advantages and weed smothering. Eur. J. Agron. 24 325-332.

Baumann, D.T., M.J.Kropf and L.Bastiaans 2000: Intercropping leeks to suppress weeds. Weed Res. 40: 361-376. 
BBS, 2011. Yearbook of Agricultural Statistics. Bangladesh Bureau of Statistics, Ministry of Planning. Govt. of the People's Republic of Bangladesh. pp.35.

Begum, S., Islam, M.N., Rahman, M. T., Chowdhury, J. A. and Haque, M.I. 2010. Suitability study of different chili varieties for intercropping with sweet gourd. J. Exp. Biosci. 1(2): 1-4.

Bhagad, S.B., S.A. Chavan, M.V. Zagade and A.V. Dahiphale. 2006. Intercropping groundnut and sweet corn at different fertility levels and row proportions. Indian J. Crop Sci. 1(1-2): 151-153.

Cruz, F.D., K. Moody and M.B.D. Ramas. 1986. Reducing variability sampling weeds in upland rice (Oryza sativa). Philopp J. Weed Sci. 13: 56-59.

Farid, A.T.M. and N.C. Shil 2006. Nutrient Management for Hybrid Maize Cultivation in Bangladesh. In: Hybrid Maize Production Technology. Training Manual. Development of Hybrid Maize Research Project. Plant Breeding Division, Bangladesh Agril. Res. Inst. 24p.

Hugar,H.Y.and Y.B. Palled. 2008. Effect of intercropping vegetables on maize associated with weeds in maize-vegetable intercropping systems. Karnakata. J. Agric. Sci. 21(2): 159-161.

Ijoyah, M.O. 2012. Review of intercropping research on cereal- vegetable based cropping system.Scientific J. Crop Sci. 1(3): 55-62.

Islam, M.N. 2002: Competitive interference in a maize-bush bean intercropping systems. Ph.D. Dissertation. Bangladesh Sheikh MujiburRahman Agricultural University, Salna, Gazipur-1703.

Islam, M.N., Rahman, M. S., Ahmed, F., Alom, M.S. and Akhteruzzaman, M. 2013. Performance of different HYV mustard varieties with sugarcane (Sacchaarum officinarum) as intercrop in farmers' fields. Bangladesh J. Agril. Res. 38(1): 137-143.

Kandasamy, S. 2017. Effect of weed management practices on weed control index, yield and yield components of sweet corn. J Agri Res. 2 (4):000139.

Karimmojeni, H., H.R.Mashhadi, H. M. Alizadeh, R.D. Cousens and M.B.Mesgaran. 2010. Interference between maize and Xanthium strumarium or Datura stramonium. Weed Res. 50: 253-261.

Kumar, K.A. and M.D. Reddy. 2000. Integrated weed management in maize + turmeric intercropping systems. Indian J. Weed sci. 32 (1\&2) :59-62.

Liebman, M. and E. Dyek. 1993. Crop rotation and intercropping strategies for weed management. Ecol. Appl. 3 : 92-122.

Mashingaidze, N. 2004. The effect of detassilling and leaf stripping on productivity and weed pressure in a maize-bean intercrop in Chinyika Resettlement area. MSc. Thesis, Crop Science Department, University of Zimbabwe. pp. 88.

Patel, V.J., P.N. Upadhyay, J.B. Patel and M.I.Meisuriya. 2006. Effect of herbicide mixture on weeds in kharif maize (Zea mays L.) under middle Gujarat conditions. Indian J. Weed Sci. 38(1\&2): 54-57.

Patra, B.C., B.K. Mandal and A.L.Padhi.2000: Production potential of winter maize (Zea mays L.) based intercropping systems. Indian J. Agril.Sci.70(4): 203-206.

Quayyum, M.A., M.E.Akanda and M.F. Karim. 1987: Row spacing and number of rows of chickpea grown in association with maize (Zea mays L.) Bangladesh J. Agril.Res.12(4) 223-230. 
Razzaque, M.A., S.Rafiquzzaman, M.M. Bazzaz, M.A. Ali and M.M.R. Talukdar. 2007: Study on the intercropping groundnut with chill at different plant populations. Bangladesh J. Agril. Res. 32(1) 37-43.

Saha, R.R., M.A.Quayyum, S.Alom, P.C.Sarker, A.Khayer, A.F.M.F. Rahman.2001: Fertilizer management in hybrid maize with soybean intercropping system under irrigated condition. J. Bio. Sci. 1(9) 812-814.

Santalla, M., A.P. Rodino, P.A. Casquero and RonAMde 2001: Interactions of bushbean intercropped with field and sweet corn. Europ. J. Agron.15 185196.

Sarker. R.K. and P.K. Pal. 2004: Effect of intercropping rice (Oryza sativa) with groundnut (Arachishypogaea) and pigeonpea (Cajanuscajan) under different row orientations on rainfed uplands. Indian J. Agron.49(3)147-150.

Singh, D.P., N.S. Rana and R.P. Sing. 2000: Growth and yield of winter maize as influenced by intercrops and nitrogen application. Indian J. Agron.45(3) 515519.

Singh, H.P., M.C. Saxena and J.P.Sahu. 1980: Harvest index in relation to yield in (legume). Tropical Grain legume 17/18: 6-8.

Sreenivas, G. and V. Satyanarayana. 1996. Nutrient removal by weeds and corn. Ind. J. Agron. 41(1) 160-162.

Thayamini, H.S. and I.Brintha. 2010. Review on maize based intercropping. J. Agron. 9(3): 135-145.

Willey RW 1979: Intercropping: Its importance and research needs. Field Crops Abs. 32(1) 1-10.

Willey RW, Rao MR 1980: A competitive ratio for quantifying competition between intercrops. Expl. Agric. 16 117-125. 